\title{
An Overview of Indonesia's Protection on Women Migrant Workers
}

\author{
Koesrianti ${ }^{1}$
}

\section{INTRODUCTION}

International migration has increased dramatically over the last four decades, particularly in high-income countries. Wealthy countries have attracted millions of people who want a better standard of living, social services, safe communities, healthy environment, and overall security. ${ }^{2}$ For instance, the current numbers of migrant laborers who work and live in the countries of the Middle East are approximately 10 million, and a majority of them are from Southeast Asia, South Asia, and Africa. Migration brings benefits to both sending and receiving states in remittances and cheap labor respectively. Currently, at least 232 million people in the world have become migrants for a variety of reasons. ${ }^{3}$

Millions of Indonesians live in foreign countries. Approximately 400,000 Indonesians are registered to have legally migrated to other countries each year since $1998 .{ }^{4}$ The actual figure is estimated to be much higher

1 LL.M. (New South Wales); Ph.D (New South Wales); Associate Professor, Faculty of Law, Universitas Airlangga.

2 Andres Solimano, International Migration in the Age of Crisis and Globalization: Historical and Recent Experiences 4 (2010).

3 Migration and Human Rights, Office of the High Commissioner for Human Rights, available at http://www.ohchr.org/en/Issues/Migration/Pages/ MigrationAndHumanRightsIndex.aspx (last visited Mar. 26, 2015). This number increased dramatically. In 2005, only 119 million people worldwide were living in a country different from the country where they were born.

4 Chitrawati Buchori \& Mia Amalia, Fact Sheet: Migration, Remittance, and Female Migrant Workers, The World Bank, 1 (2006), http://www-wds. worldbank.org/external/default/WDSContentServer/WDSP/IB/2009/ 10/26/000333037_20091026001512/Rendered/PDF/512450WP0Box341actsheet migrationeng.pdf.

A large number of migrants today move between developing countries, and 
because many migrate illegally. ${ }^{5}$ Some migrant workers are considered as documented or in a regular situation, while others are considered as undocumented or in an irregular situation based on their administrative status under national immigration laws. The latter also can be referred to as illegal migrant workers and treated differently by their destination states. The real number may be twice or three times bigger, partly due to the high incidence of undeclared domestic work and the fact that national statistics often do not count domestic workers as a distinct category. Pursuant to the regulations and migration policies, Indonesian agencies are obliged to report data of migrant workers to the Indonesian Embassy of the destination countries but these agencies often ignore this obligation. ${ }^{6}$

The Ministry of Foreign Affairs stated that the total number of Indonesian citizens who reported to the Indonesian Embassy in foreign countries is more than three million as can be seen in Table 1. Approximately 30\% of this total number represents migrant workers. Indonesian migrant workers have been called "foreign exchange heroines" as they send a large amount of their remittance to Indonesia every year. ${ }^{7}$ However, the National Agency for the Placement and Protection of Overseas Labor (Badan National Penempatandan Perlindungan Tenaga Kerja Indonesia, BNP2TKI) claims that there are at least six million Indonesian migrant workers in the formal and informal sectors.

\begin{tabular}{|l|r|r|}
\hline Destination country & Total number & Percentage \\
\hline Malaysia & $1,410,787$ & $42 \%$ \\
\hline Saudi Arabia & 641,039 & $19 \%$ \\
\hline Middle East & 379,963 & $11 \%$ \\
\hline
\end{tabular}

around forty percent (40\%) of the total global migrants have moved to a neighboring country within their region of origin.

$5 \quad I d$.

6 Tatang Budi Utama Razak, Director of Protection Indonesian Citizens and Legal Entities, Ministry of Foreign Affairs, Address at Workshop on the Improvement Capacity of District Civil Servant in Implementing Diplomacy and Technical Cooperation (Mar. 21, 2013).

7 Imam Bukhori, Remitansi TKI Tahun 2013 Capai RPG 81.34 Trilyun, BADAN National Penempatandan Perlindungan Tenaga Kerja Indonesia (Dec. 23, 2013, 7:06 AM), http://www.bnp2tki.go.id/read/8591/ Remitansi-TKI-Tahun2013-Capai-Rp-8134-Trilyun. In 2013, the remittance was Indonesian Rupiah (IDR) 81,345 billion or equivalent to USD 7,395,017,768. 


\begin{tabular}{|l|r|r|}
\hline Destination country & Total Number & Percentage \\
\hline East Asia & 359,844 & $11 \%$ \\
\hline Southeast Asia & 249,100 & $7 \%$ \\
\hline United States of America & 130,851 & $4 \%$ \\
\hline Europe & 59,735 & $2 \%$ \\
\hline Pacific Countries & 55,591 & $2 \%$ \\
\hline Africa & 4,439 & $1 \%$ \\
\hline South Asia & 2,760 & $1 \%$ \\
\hline Total & $3,294,109$ & $100 \%$ \\
\hline
\end{tabular}

Table 1: Destination countries and total number/percentage ${ }^{8}$

In 2014, the number of Indonesian migrant workers making a living in the Middle East was 1,269,000; of this number, 1,009 migrant laborers live in Saudi Arabia. ${ }^{9}$ They fill employment and make significant contributions to the host country's economy as well as to their families back home. They are often found working in jobs that are dirty, dangerous, and degrading (so-called 3D jobs) that people in the receiving state do not wish to do. ${ }^{10}$

The number of migrant workers - especially female workers - has been increasing throughout the decades due to the demand for migrant women to fill low-wage service work in many cities throughout the world. However, the reports of violations and abuse of migrant workers' rights have also been escalating significantly. ${ }^{11}$ These violations include inhumane

8 Tatang Budi Utama Razak, supra note 6.

9 Number of Indonesian Migrant Workers by Host Country, BANK Indonesia \& BNP2 2 PKI, 1, http://www.bi.go.id/seki/tabel/TABEL5_30.pdf (last visited Mar. 26, 2015); See also Gazafar Ali Khan, Indonesian Mission Working Toward Solving 32 Maids Cases, Ara B News (June 26, 2012), http://www.arabnews.com/indonesianmission-working-toward-solving-32-maids-cases.

10 See John Connell, Kitanai, Kitsui, and Kiken: the Rise of Labor Migration to Japan (Economic \& Regional Restructuring Research Unit, Working Paper No. 13, 1993). $3 \mathrm{D}$ jobs are often defined as dirty, dangerous and demeaning/demanding. This terminology came from the Japanese term " $3 \mathrm{~K}$ ” referring to kitanai, kiken, kitsui. These jobs are described as high risk and of low status.

11 Sevil Sonmez et al., Human Rights and Health Disparities for Migrant Workers in the UAE, HHR (Dec. 2011), available at http://www.hhrjournal.org/wp-content/ uploads/sites/13/2013/06/Sonmez21.pdf. For example, the total cases in 2011 was 38,880 and the total number of Indonesian migrant workers subject to the 
treatment, unsafe working conditions, non-payment of wages and multiple deductions, unreasonable working hours and conditions, physical and verbal abuse, accidents and illnesses, as well as unfair treatment in legal proceedings. ${ }^{12}$ Related to these violations, domestic workers even have less recourse when their rights are violated since they are systematically excluded from most labor law protection. As a consequence, they receive less protection than workers engaged in other types of labor if they receive one at all.

While some Indonesian female domestic workers find being a migrant a positive and empowering experience, for others, it can be a bitter experience as they have to endure human rights violations, discrimination, and exploitation. Indeed, the migrant workers have less legal protection compared to local workers. Although some destination countries have employment laws that provide rights and obligations for migrant workers, the lack of effective enforcement and the migrant workers' dependence on their employers and recruitment agents, lead them to have few or no safeguards against abuse. To some extent, migrant workers, particularly informal female migrant workers, are considered vulnerable. Many migrant workers face violence and abusive treatments within the entire spectrum of their migration. Therefore, Indonesia, as the sending state, should provide adequate protection to female migrant workers.

This article attempts to identify the root of the problem of vulnerable, informal Indonesian migrant workers and evaluate their protection based on the concept of the state responsibility. It discusses the responsibility of Indonesia over migrant workers, especially Indonesian female domestic migrant workers. This article analyzes the concept of state responsibility over informal migrant labor that requires the provision of protection during the entire process of employment including the stages of pre-departure, employment, and their return home. It simultaneously reviews Indonesian government policies and regulations as well as the institutions that deal

death penalty was 231; Tatang Budie Utama Razak, Perlindungan Warga Negara Indonesia di Luar Negeri: Proyeksi dan Tantangan, Rapat Koordinasi Nasional Perlindungan Warga Negara Indonesia 2013, Jakarta, (Aug. 18, 2013).

Research Center of Indonesian Foreign Affairs Ministry \& Unit Centre for Law Protection of Legal Entities and Citizens Abroad Law Faculty Universitas Airlangga, Buku Petunjuk Teknis 45 (2011). 
with migrant worker protection. Lastly, this article draws conclusions and provides suggestions for improvement.

\section{INDONESIAN WOMEN MIGRANT WORKERS}

According to the Indonesian Ministry of Foreign Affairs, of the 3,965,000 Indonesian migrant workers, $67 \%$ are women. ${ }^{13}$ More than $90 \%$ of Indonesian female migrant workers work in the informal sector as domestic workers while the rest work in agricultural and industrial sectors as day laborers, caregivers to the elderly, shop assistants, and waitresses. ${ }^{14}$ Thus, a majority of Indonesian female migrant workers work informally in the receiving states.

Due to the characteristic of their work being domestic in nature, housemaid workers are a vulnerable group. Indonesian housemaid workers face work-related problems including unpaid work, physical abuse, sexual harassment, overwork, dissatisfaction, disagreements with their employer, sickness, and the possibility of facing death penalty. ${ }^{15}$ Of these problems, the death penalty is the most serious and this has escalated the tension in Indonesian society due to frequent news media reports on their plight.

Most of the violations of rights are suffered by Indonesian unskilled domestic migrant workers. There are reports of abuse upon Indonesian female migrant workers by their Saudi Arabian employers including physical abuses and in some cases have led to the death of Indonesian maids. ${ }^{16}$ In addition, some were even arrested on alleged charges of murder, witchcraft, and sexual offenses, and were subject to threats of the death penalty. ${ }^{17}$ As indicated in Table 1 above, Malaysia and Saudi Arabia are the two biggest receiving countries of Indonesian migrant workers. Therefore, the problems of Indonesian migrant workers frequently occur in these two destination countries. In Saudi Arabia, Indonesian migrant workers are largely located in Riyadh and Jeddah, 225,453 (35\%) and 415,586 (65\%)

\footnotetext{
13 Tatang Budi Utama Razak, supra note 6.

14 Buchori \& Amalia, supra note 4.

15 Tatang Budi Utama Razak, supra note 11.

16 Statement Migrant Day 2011: Pemerintah Masih Mengingkari Tanggung Jawab Perlindungan Buruh Migran, Migrant Care, available at http://www.migrantcare. net/mod.php?mod=publisher\&op=viewarticle.
}

17 Gazafar Ali Khan, supra note 9. 
respectively. ${ }^{18}$ Meanwhile in Malaysia, most migrant workers reside in Kuala Lumpur 620,817 (44\%), in Penang 298,318 (21\%), in Johor Bahru 202,352 (14\%), in Kuching 254,111 (18 \%) and in Kinabalu City 35,189 $(3 \%) .{ }^{19}$ These two countries are the most popular destination for migrant workers because of cultural and religious reasons. ${ }^{20}$

The number of closed cases in 2012 that were reported to the National Agency for Placement and Protection of Indonesian Migrant Workers was 2,714 cases. These included case involving unpaid wages (590), no communication (640), jobs not compatible with the employment contract (216), death in destination countries (164), disatisfied migrant workers (153), abusive treatment by employers (141), sickness (112), unsuccessful job placement (81), unfair termination (59), sexual harrasment (45), deduction of wages (45), and accidents in the workplace (33). ${ }^{21} \mathrm{Up}$ to September 2012, of the 5,934 cases of Indonesian domestic migrant workers abroad, 3,484 cases were closed and the rest were in the processes of finalization. ${ }^{22}$ Many respondents indicated that the source of these problems was rooted within Indonesia itself, namely, the pre-departure process of labor migration.

In some cases, as soon as the migrant travels abroad, the attitude of the authorities appears to change as they determine that legal responsibility is transferred to the foreign employers and the destination countries. However, as with the destination countries, the home country should also be responsible for the migrant workers especially when they are injured in the foreign host country. Migrant workers deserve protections since the labor

18 Tatang Budi Utama Razak, supra note 11.

19 Tatang Budi Utama Razak, supra note 6.

20 Koesrianti, Paper presented at the 7th Asian Law Institute Conference: The Role of the ASEAN Declaration on the Protection and Promotion of the Rights of Migrant Workers for Indonesia in Giving Protection to Its Migrant Workers (May 25, 2010). See also Pande Ketut Trimayuni, Undocumented Women Indonesian Migran Workers Abroad: a Malaysia Case Study, PPIUK (2007), http://ppiuk. org/archive/ejournalfolder/4/ Undocumented_Women_Indonesian_Migrant_ Workers_Abroad.pdf.

21 Dalam Setahun Crisis Center BNP2TKI Selesaikan 2.714 Kasus TKI, BADAN National Penempatandan Perlindungan Tenaga Kerja Indonesia (June 27, 2012, 5:00 PM), http://www.bnp2tki.go.id/read/ 6309/Dalam-Setahun-CrisisCenter-BNP2TKI-Selesaikan-2.714-Kasus-TKI.

22 Id. 
companies receive the benefits of migrant labor as much as the governments of the receiving countries along with the workers' home countries.

The entire process of migrant labor comprises of recruitment, preparation for migration, departure, employment, and return to Indonesia. With this process, the main problem for the protection of Indonesian migrant workers begins with the recruitment process in Indonesia. At least three reasons for this problem can be identified:

1. Poverty and education are the major reasons for migration. The majority of migrant workers who are sent to receiving states are unskilled and poor.

2. Migrant works have become commercial objects for recruiting agents as the more workers they are able to obtain, the more profit they gain. Therefore, many Indonesian migrant workers are recruited through dishonest claims made by brokers and middlemen. Work candidates often do not fully understand the scope of the work and are generally unaware of the destination countries which they are being sent to.

3. Migrant work is a very profitable business for some people and institutions including "persons" from government institutions and agencies that face "conflicts of interest" between them. In addition, these "conflicts of interest" lead to a weak and poor recruitment and job-placement process.

In sum, all of factors weaken the bargaining position of the Indonesian government with the receiving states in providing protection to migrant workers.

\section{THE CHARACTERISTIC OF THE WOMEN'S MIGRANT DOMESTIC WORK}

The International Convention on the Protection of the Rights of All Migrant Workers and the Members of Their Families (ICRMW) ${ }^{23}$ defines the term "migrant worker" as any person who "is to be engaged, is engaged or

23 The International Convention on the Protection of the Rights of All Migrant Workers and the Members of Their Families, Dec. 18, 1990, 2220 U.N.T.S. 3 [hereinafter ICRMW]. It is the most comprehensive international treaty in the field of migration and human rights. It has been ratified by forty-one countries; 
has been engaged in a remunerated activity in a State of which he or she is not a national." 24 The ICRMW is an instrument of international law that is meant to protect migrant workers whether they are in regular or irregular situations. ${ }^{25}$ The ICRMW is an attempt to ensure that a broad range of human rights (civil and political, and economic, social and cultural) is accessible to migrant workers. It should be noted that the group of people that are vulnerable to unfair treatment includes legal immigrants, asylum seekers, and refugees. One group, referred to as undocumented immigrants, is asylum seekers who are denied permanent residence permits, or people who overstayed or stayed in the destination countries longer than their visa allowed. ${ }^{26}$ Overstayers are considered illegal migrants.

Most of the provisions of the ICRMW offer a more precise interpretation of human rights in the case of migrant workers, and establish a few new rights specific to the condition of migrants, such as the right to transfer remittances or to have access to information about the migration process. ${ }^{27}$ In short, the ICRMW is a major step towards the protection of migrant workers' rights. This means that "everyone" referred to in human rights instruments "really means every human being, that non-citizens are covered and protected by most of the provisions of human rights instruments, and that these instruments also apply to immigration law . . . this may appear self-evident today. It surely was not . . in the early 1970s." ${ }^{28}$

most of them are described as "sending countries" such as Mali, Philippines, and Sri Lanka. Indonesia ratified ICRMW on Apr. 12, 2012 by Law 6/2012.

$24 I d$. art. 2. Article 3(d) states that refugees and stateless persons are only included under the Convention if such application is provided in national legislation.

25 Regular situation refers to documented migrant workers while irregular situation refers to undocumented migrant workers.

26 Walter Deville, The Right to Health Care for Vulnerable Population Groups in the Netherlands and in Europe, in Human Rights and Biomedicine 87, 89 (Andre den Exter ed., 2010).

27 Paul de Guchteneire \& Antoine Pecaud, Introduction: the UN Convention on Migrant Workers' Right, in Migration and Human Rights: the United Nations Convention on Migrant Workers' Rights 1, 8 (Paul de Guchteneire et al. eds., 2009).

28 Kees Groenendijk, Introduction to Irregular Migration and Human Rights: Theoretical, European, and International Perspectives xvii, xix (Barbara Boguszet et al. eds., 2004). 
Based on the qualification of jobs in destination countries, migrant workers are divided into formal and informal migrant workers. ${ }^{29}$ Domestic migrant workers are one of the categories of informal workers that are similar to gardeners, plantation workers, construction employees, and transportation and services workers. The ICRMW excludes from the scope of its application a number of categories of workers ${ }^{30}$ and is silent about domestic migrant workers.

It can be said that domestic work is an important occupation for millions of individuals, accounting for up to $10 \%$ of total employment in some countries. ${ }^{31}$ The trend over the past decades has been a growing prevalence of migrants amongst domestic workers. Women make up the overwhelming majority of these workers. ${ }^{32}$ However, for a long time, there has been an omission of explicit references to either domestic work or domestic workers in a broad range of national and international legal frameworks. In other words, there is no proper protection for domestic workers. Protections are further lacking when they work as housemaids in foreign countries. Being a woman worker is worse since they are subjected to additional exploitation and abuse.

Compared to domestic laborers who work in their own countries, domestic migrant workers are confronted with several human rights issues. Generally, migrant domestic workers are at heightened risk of certain forms of exploitation and abuse. Residing in foreign countries is the hardest

29 While formal workers are people who work in proper workplaces with permanent official contract arrangements, informal workers are people who work based on less formal contract arrangements. They can be freelancers or temporary laborer, and their activities and income are partially or fully outside government regulation, taxation, and observation.

30 See ICRMW, supra note 23, art. 3. They are international organizations employees, employee of co-operation programs, investors, refugees and stateless persons, students and trainees, and seafarers and workers on an offshore installation.

31 See International Labour Organization, Report IV(1): Decent Work for Domestic Workers (2009). There is no accurate data on the number of domestic workers throughout the world, partly due to the high incidence of undeclared domestic work and the fact that national statistics often do not count domestic workers as a distinct category. However, such available data shows that domestic work accounts for between 4 and $10 \%$ of total employment in developing countries and between 1 and $2.5 \%$ in industrialized countries.

32 Id. 
experience for uneducated Indonesian female domestic migrant workers as they become a "nobody" once they arrive in the destination countries. The center of their vulnerability is isolation and dependence which can be described in the following:

1) an isolated life, far away from home and family, in a foreign land and surrounded by foreign language;

2) lack of basic support systems and unfamiliarity with the culture and national labor and migration laws;

3) dependence on their job and employer because of migrationrelated debt and legal status;

4) the practices of employment that restrict them from leaving their job; ${ }^{33}$

5) the simple fact that the migrants' workplace may also be their only shelter; and

6) the family members' reliance on remittances that the migrant workers send back home.

A majority of those who are employed as domestic workers are women. It can be said that there are some additional risks for women migrant domestic workers, namely gender-based violence, ranging from sexual harassment to rape. The risks and vulnerabilities are further worsened for migrant domestic workers who are undocumented or in an irregular situation because they often risk deportation if they contact the state authorities to seek protection from an abusive employer. Thus, women domestic migrant workers have multiple risks for certain forms of exploitation and abuse because of the nature of domestic work as well as the capacity of their individual human resources. This is because usually those who want to do this type of work are less educated than those who are engaged in other types of work as it requires little schooling and no formal qualification.

33 For Indonesian migrant workers, the employment contract period usually lasts for two years. The domestic migrant workers cannot leave their workplace before this two-year contract ends. However, this contract can be renewed after the migrant workers go back to Indonesia. 
The treatment of domestic workers would change in June 2011 since domestic work was recognized as work equal to other types of formal work when the International Labour Organization (ILO) adopted the historic Convention (No. 189) Concerning Decent Work for Domestic Workers in 2011 and accompanying Recommendation No. 201. ${ }^{34}$ Convention No. 189 defines domestic work as "work performed in or for a household or households." The work may include tasks such as, housing cleaning, cooking, washing and ironing clothes, taking care of children, elderly, or sick members of family, gardening, guarding a house, driving a family, and even taking care of household pets.

\section{INDONESIA'S RESPONSIBILITY TO PROTECT}

In this globalized world, millions of people work outside their country of origin including Indonesian migrant workers. Indonesia has sent formal and informal workers abroad to places such as Saudi Arabia, Hong Kong, Taiwan, Malaysia, and Singapore. If an Indonesian migrant worker is suffers a legal injury, this will incur responsibility of one state to another for the injuries it has caused. ${ }^{35}$ It is a basic principle of international law that a state that causes an injury to a foreign citizen (national) is responsible to the national's state for the harm done, not to the national herself. ${ }^{36}$ The rationale is that an injury to a state's national is an injury to that state.

To establish that a state is responsible for an injury caused to an alien or foreign business, there must be (1) "conduct consisting of an action or omission ... attributable to the State under international law;" and (2) the conduct must "constitute ... a breach of an international obligation of the

34 Convention (No. 189) concerning Decent Work for Domestic Workers, June 16, 2011 [hereinafter Convention No. 189]. The Recommendation provides practical guidance concerning possible legal and other measures to implement the rights and principles stated in the Convention without need for ratification by states.

35 Rachel Silvey, Transnational Domestication: State Power and Indonesian Migrant Women in Saudi Arabia, 23 Political Geography 245, 248 (2004).

36 Emmerlich de Vattel, The Law of Nations 156 (1758) "Whoever ill-treats a citizen indirectly injuries the state, which must protect the citizen" cited in Lawrence Jahoon Lee, Barcelona Traction in the 21th Century; Revisiting its Customary and Policy Underpinnings 35 years Later, 42 STANFORD JOURNAL OF INTERNATIONAL LAW 237 (2006). 
State." ${ }^{37}$ State governments are only responsible for the actions taken by their officials and are not responsible for the acts of private persons, insurrectionists, or rebels within their own territories as held in the Home Missionary Society Case (1920). ${ }^{38}$ In this case, the state government was not found to be negligent or have acted in bad faith in suppressing the insurrection. In regard to the abuse toward migrant workers' rights, all states should respect, protect and fulfill workers' rights wherever they live, considering their contribution to states' development. This is relevant, given the fact that across the entire spectrum of migration - from recruitment to employment to return - the workers occasionally face exploitation and abuse. Therefore, not only does the protection to migrant workers apply when the migrants are actually working, but also during the entire process of their migration including preparation, departure, transit, and the entire period of stay and remunerated activity in the destination state as well as the return to their state of origin or the state of their habitual residence.

Basically, the sending state is responsible for the entire process of migration which is comprised of three stages: pre-departure, on-site job/ employment, and the return home stage. Of these stages, the protection of migrant workers in the employment stage when the migrants are actually working is the most difficult task due to the fact that the workers are abroad or outside the jurisdiction of the sending states. However, this does not mean that the other two stages are less important than the employment stage as the capability and capacity of workers are enhanced thoroughly in those stages. It can be said that the success of migrant workers abroad fully depends on the pre-departure stage. The problems of migrant workers would decrease significantly if the sending state sent qualified workers abroad. Notably, of the total problems Indonesian migrant workers face abroad, around $80 \%$ of their problems originated from the pre-departure stage. In short, the inadequate protection of migrant workers abroad begins from the pre-departure phase which consists of recruitment, training, document handling, and related issues. It should be noted that female

37 Rep. of the Int'l Law Comm'n, 53d Sess., Apr. 23-June 1, July 2-Aug. 10, 2001, U.N. Doc. A/56/10; GAOR, 56th Sess., Supp. No.10 (2001).

38 U.N. Office of Legal Affairs, Reports of International Arbitral Awards: Home Frontier and Foreign Missionary Society of the United Brethren in Christ (United States) v. Great Britain, at 42, U.N. Sales No. 1955.V.3 (2006). 
domestic migrant workers are the biggest and most exploited group due to the scope of their work and the looseness of administrative recruitment caused by low educational requirements and the lack needing formal qualifications. The sending state's responsibility over the three stages of the migration process is described below.

The process of recruitment consist of elements such as job information, training, and document handling including employment contracts, and securing information on the destination countries. At this stage, vulnerable and unemployed female villagers are recruited by dishonest and unregulated agencies. In many cases, a "sponsor" or labor broker provides job information as well as manages of the recruitment process. ${ }^{39}$ For many villagers in Indonesia ${ }^{40}$ a job abroad is seen as a ticket out of poverty. Some of them often sell everything they or their families own and borrow heavily to pay unscrupulous labor brokers and recruitment agencies. The fee for brokers or sponsor is around nine billion IDR per person for arranging travel and the placement of a job abroad. ${ }^{41}$ As a consequence, many Indonesian migrant workers are trapped for months in debt bondage because of excessive fees and bribes. Most of them work as low-wage domestic workers abroad. They have to pay their debt when they are working abroad. They cannot have their earnings for at least the first six or eight months of their employment because they have to pay off their debt.

Currently, the government has launched Microfinance Credit (Kredit Usaha Rakyat, KUR) for Migrant Workers that has its purpose to help migrants cover the costs incurred during their transition. ${ }^{42}$ The credit scheme

39 Rusjdi Basalamah, Address at Strategi Peningkatan Kualitas Sistem Perekrutandan Pelatihan TKI, Lokakarya Nasional Perlindungan TKI di LuarNegeri (Mar. 24-25, 2010).

40 Many provinces in Indonesia are categorized as "kantong TKI" (pockets of migrant workers) in Indonesia, namely, East Nusa Tenggara, West Nusa Tenggara,West Java, East Java, Bali, Lombok, and Lampung.

41 Basalamah, supra note 39.

42 For example, concerning the Scheme adopted on Jan. 24, 2012, the Head of Regulations for BNP2TKI stated that the credit scheme for Singapore is IDR $10,933,000$ with interest and an administrative fee, new migrant workers should pay IDR $14,336,000$ which is calculated to equal eight-months' wage; while for currently residing migrant workers, it is IDR 5,448,000 with interest and an administrative fee for a total of IDR 7,168,000. 
is designed based on the destination countries of the migrants. Accordingly, this scheme can appear to ease the burden of migrant workers, but it is unable to achieve its purpose because the amount of credit needed is still relatively high for migrant workers. Thus, the migrant workers need to stay abroad to pay off the debt with six to eight months of their wages. Furthermore, in order to get more candidates, brokers often manipulate identification documents. ${ }^{43}$ As a consequence, most candidates are younger than the official requirement. They may considered child laborers. This problem is difficult to eradicate due to the dishonesty of labor brokers and because it is an indirect consequence of the recruitment system by the agencies and private labor companies. Many villagers are trapped into human trafficking. The Indonesian government should cut this migration chain by optimizing the role of provincial governments in the process.

Another important issue is the handling of employment contracts. A majority of workers do not understand the substance of their contract because the contract documents, in many cases, are prepared by the agencies and given to the workers just before they take off to go to the destination countries. Therefore, there is no opportunity for them to carefully review the employment contract. Moreover, they cannot understand the substance of the contract because the contracts are usually in English. At this stage, there needs to be state intervention in mediating employment contracts abroad as a form of state responsibility to migrant workers.

Another process is the training program. Before going abroad for the job, the candidates have to attend training programs, namely language and skills training programs. In many cases, the training programs are held as a formality rather than a sincere effort to develop the candidates' skill in order to improve the quality of candidates. ${ }^{44}$ Language skills and information on culture, law of the destination states, including the sponsorship system (kafala) are also important parts of this training. ${ }^{45}$ Notably,

43 Documents that should be provided by the candidates are ID Card (KTP); Family Identification Card (Kartu Keluarga); birth certificate; and a letter from parents or husband stating their permission for the candidate.

44 Basalamah, supra note 39.

45 See Gwenann S. Manseau, Contractual Solutions for Migrant Labourers: The Case of Domestic Workers in the Middle East, 2 Human Rights Law Commentary 25 (2006), available at http://www.nottingham.ac.uk/hrlc/documents/publications/ hrlcommentary2006/migrantlabourers.pdf. Sponsorship system or Kafala is a 
Saudi Arabia has a different culture as well as law from Indonesia. Thus, all of these skills, training, and knowledge are critical for the survival of Indonesian migrant workers abroad.

\section{CHALLENGES IN PROTECTING WOMEN MIGRANT WORKERS}

The state responsibility of the sending state is important when migrant workers abroad face work-related problems or serious criminal offenses. In some receiving countries, many of them are unable to enjoy freedom of movement since their employers or brokers withhold their passports and wages. For example, Malaysian employers often withhold the passports of their migrant Indonesian housemaids for "security". ${ }^{46}$ Many of them work and live in sub-standard conditions when they work in destination countries. For many migrant workers, the hope of building a better life for their families soon fade when they realize that they must use the majority of their wages for loan repayment. While migrant workers basically are protected under the international law of human rights, ${ }^{47}$ however, they are not allowed to form or join trade unions, so they cannot organize themselves to bargain collectively for better pay and conditions. They sometimes are physically abused or sexually exploited and can end up being trafficked into various forms of modern-day slavery. Access to justice for those who face such abuses is rarely available or affordable. Therefore, the intervention of the sending state to provide protection for migrant workers in receiving countries is critical.

sponsorship system officially used as recruitment system to find a temporary worker from abroad (usually for 2 years) involving the service of manpower recruitment agencies in Saudi Arabia.

46 Amnesty International, Malaysia Must End Abuse of Migrant Workers, at www. amnesty.org/en/news-and-updates/report/malaysia-must-end-abuse-migrantworkers-2010-03-24; see also, Lilian Budianto, Indonesia and Malaysia close to deal on Protection Migrant Workers, The Jakarta Post, 08 February 2010, under this 2010 deal, Malaysian employers have the right to hold employees' passports while the workers are given identity cards issued by Malaysian authorities.

47 Report of the International Commission on Intervention and State Sovereignty: Responsibility to Protect, Canada, 2001, at 36; see also The International on The Protection of The Rights of All Migrant Workers and Their Members of their Families, Article 7 on Non-Discrimination with Respect to Rights. 
The problems of Indonesian migrant workers are very complex and involve many elements of Indonesian bureaucratic government policies as well as the national immigration regulations of destination states. A majority of the cases involving Indonesian migrant workers have occurred in countries where the national labor law gives weak protection to migrant workers which leads to arbitrary conduct by employers and agencies towards them. In other words, a part of the protection that Indonesian migrant workers rely on is the national labor regulations of receiving states. Indonesia is able to conclude a bilateral agreement or Memorandum of Understanding (MOU) with the receiving state in order to give protection to their migrant workers who work in the receiving state. The Indonesian government can elaborate and provide for Indonesian migrant workers' rights in the MOUs, including the rights for sick-leave and vacations or other migrant workers' rights provided for in the ILO conventions. To give more protection to migrant workers abroad, the Indonesian government already has bilateral agreements or MOUs with the following nine countries: United Arab Emirates, Kuwait, South Korea, Taiwan, Malaysia, Qatar, Jordan, Hong Kong, and Japan. ${ }^{48}$

Even though Indonesia has MOUs on migrant workers with destination states, these MOUs cannot directly give protection to migrant workers individually as a MOU cannot replace the national labor laws of destination states. For example, the minimum wage provision in the MOU cannot be materialized if the national labor law is enacted to give effect to the provision. Indeed, most MOUs are concern with and designed to provide standards for regulations and administrative procedures concerning placement and acceptance of migrant workers in receiving states and do not include protection for migrant workers. ${ }^{49}$ For instance, if Indonesia intended to insert protection provisions in a MOU, this kind of protection is merely an indirect protection in the form of cooperation between Indonesia and destination states. However, the application of the MOU would still be limited especially when it conflicts with the labor law of destination states.

48 Roostiawati, Address at Perlindungan TKI di Luar Negeri, Perluasan Kesempatan Kerjadan Peningkatan Pelayanan Penempatan, Lokakarya Nasional Perlindungan TKI, Surabaya (Mar. 24, 2010).

49 Lisa Thomas, Worker Protection, TIME, July 28, 2009, http://content.time.com/ time/world/article/ 0,8599,1913134,00.html. 
The protection of Indonesian migrant workers can still be ensured by having a proper employment contract between the employer and migrant worker as the employee. So far, the contract is prepared by the agent since most migrant workers are less educated which can lead to weak protection for migrant workers. The circumstances are further complicated in Saudi Arabia where foreign workers should have employment contracts written in Arabic in order to be issued a work permit. ${ }^{50}$

\section{a. Diplomatic Protection of Sending States}

In relation with the protection of migrant workers, sending states can intervene based on the principle of diplomatic protection, as an injury to a national of a state is an injury to the state itself. ${ }^{51}$ Diplomatic protection is the right of a state to espouse a claim on behalf of its nationals injured by the wrongful conduct of another state. ${ }^{52}$ The sending states, based on the law on the international responsibility of states for injuries to aliens, can make a claim to the defendant state. Although the receiving states "are not obliged to admit aliens to their territory ... if they permit aliens to come, they must treat them in a civilized manner." ${ }^{53}$ Furthermore, Malanczuk explains that:

50 Manseau, supra note 45.

51 Alberto Alvarez-Jimenez, Foreign Investors, Diplomatic Protection and the International Court of Justice's Decision on Preliminary Objections in the Diallo Case, 33 North Carolina Journal of International Law \& Commercial REGULATION 437, 438 (2008) (“[W]hoever ill-treats a citizen indirectly injures the State, which must protect the citizen.") (quoting Emmerlich de Vattel, The LaW of Nations or the Principles of Natural Law Applied to the Conduct and to the Affairs of Nations and Sovereigns Vol. III 136 (James Brown Scott ed., Charles Fenwick trans., 1916) (1758)).

52 Rep. of the Int'l Law Comm'n, 52nd Sess., Mar. 7, Apr. 20, 2000, U.N.Doc.A/ CN.4/506 (2000). Article 1(1) of the draft articles on diplomatic protection states that "diplomatic protection means action taken by a State against another State in respect of an injury to the person or property of a national caused by an internationally wrongful act or omission attributable to the latter State." Id.

53 Peter Malanczuk, Akehurst's Modern Introduction to International LAW 256 (Routledge 7th rev. ed. 1997). See also Barcelona Traction, Light and Power Company, Ltd (Belg. v. Spain), 1964 I.C.J. 6 (July 24). 
[F]ailure to comply with the minimum international standard 'engages the international responsibility' of the defendant state, and the national state of the injured alien may 'exercise its right of diplomatic protection', that is, may make a claim, through diplomatic channels, against the other state, in order to obtain compensation or some other form of redress. ${ }^{54}$

The sending states should have a genuine link with the injured alien through nationality. The bond of nationality gives the sending state legal standing to exercise diplomatic protection on behalf of an injured national. ${ }^{55}$ Thus, nationality is the basis of the legal interest in an indirect claim of the sending state. ${ }^{56}$ In relation with this issue, the International Court of Justice in the Nottebohm Case (1955) stated that:

According to the practice of States, to arbitral and judicial decisions and to the opinions of writers, nationality is a legal bond having as its basis a social fact of attachment, a genuine connection of existence, interests and sentiments, together with the existence of reciprocal rights and duties. It may be said to constitute the juridical expression of the fact that the individual upon whom it is conferred ... is in fact more closely connected with the population of the State conferring nationality than with that of any other State. Conferred by a State, it only entitles that State to exercise protection vis-à-vis another State, if it constitutes a translation into juridical terms of the individual's connection with the State which has made him its national. ${ }^{57}$

However, it should be noted that "[o]nce a State has taken up a case on behalf of one of its subjects ... the State is [the] sole claimant." ${ }^{28}$ This is because the basic proposition of international law is that it is a state-oriented world system. Thus, it is only through the medium of the state that individuals

$54 \quad I d$.

55 Phoebe Okowa, Issues of Admissibility and the Law on International Responsibility, InTERNATiONAL LAW 477 (Malcolm D. Evans ed., 2003)

$56 \quad I d$.

57 Nottebohm (Liech. v. Guat.), 1955 I.C.J. 3 (Apr. 6).

58 Mavrommatis Palestine Concessions (Greece v. Gr. Brit.), 1924 P.C.I.J. (ser. A) No.2 (Aug. 30) (stating that a claim on the international level is considered to be that of the state whose citizen has been mistreated by the defendant state). 
may obtain the full range of benefits available under international law, thus nationality is the key. ${ }^{59}$

Besides diplomatic protection, international human rights can be used as another means of giving protection to migrant workers in host countries. International human rights law protects individuals regardless of their nationality; indeed, it protects human beings as such. Accordingly, Indonesian female domestic migrant workers are protected by the Convention on the Elimination of All Forms of Discrimination against Women. Thus, under these norms, the sending states as well as receiving states are responsible for the protection of all migrant workers, indeed, all of the states should respect, protect and fulfill human rights obligations as illustrated below in the chart below detaling the scope of human rights obligations. ${ }^{60}$

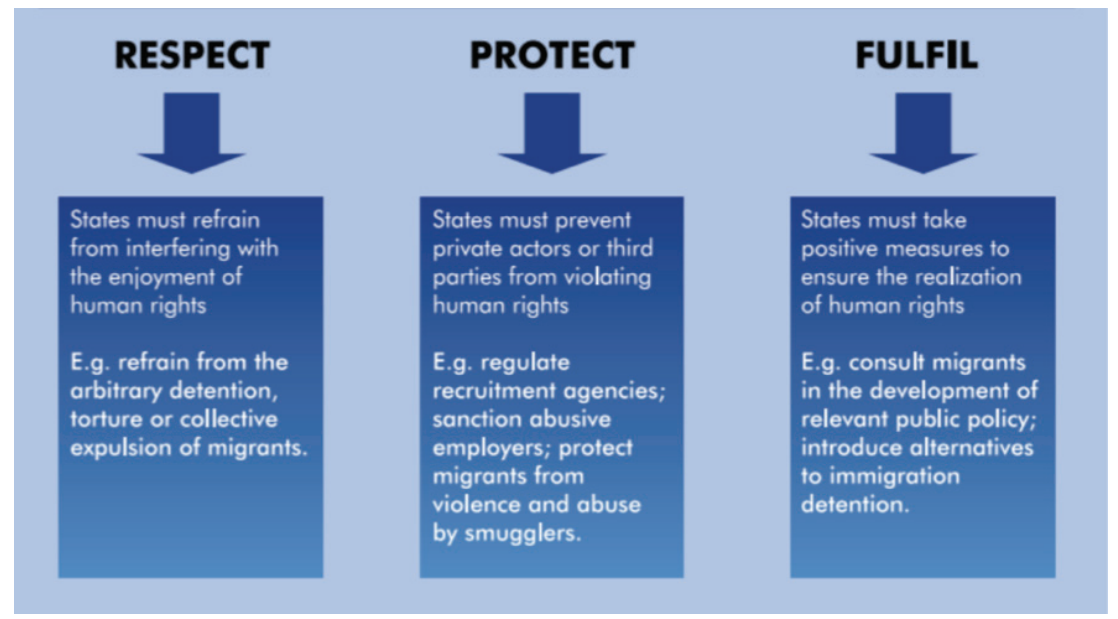

Referring to the objects of protection, international human rights differs from state responsibility, as reflected in the opinion of Buergenthal and Maier as follows:

The law of state responsibility protects individuals against violations of their rights only when their nationality is not that of the

59 Malcolm N. Shaw, International Law 809 (2008).

60 See United Nations Human Rights, Migration and human rights: Improving Human Rights-Based Governance of International Migration (2011), available at http:// www.ohchr.org/Documents/Issues/Migration/MigrationHR_improvingHR_ Report.pdf. 
offending state; international human rights law protects individuals regardless of their nationality. The concept of nationality is irrelevant in human rights law because the individual is deemed to be the subject of these rights. Nationality is of vital importance however, under the law of state responsibility because here the injury to a national is deemed to be an injury to the state of his/ her nationality. ${ }^{61}$

As human beings, domestic migrant workers should be protected by international human rights law just like other worker groups. Domestic work however is still undervalued. The people who work in this sector have low status in the community and are marginalized. Indonesia has sent around 650,000 domestic migrant workers abroad every year. ${ }^{62}$ Therefore, their protection has become crucial for the government. The government intends to decrease the number of domestic migrant workers over the years: indeed, for the last three years the numbers have gradually decreased. ${ }^{63}$

\section{b. Protection in the Employment Stage: Migrant Workers Abroad}

The Indonesian government has adopted regulations and policies on the placement and protection of migrant workers, and established institutions to protect their rights. The main legal instrument for the protection of migrant workers is Law 39/2004 ${ }^{64}$ concerning the Placement and Protection of Indonesian Migrant Workers Abroad (Law 39), President Instruction 6/2006 concerning the Government Policies on Reformation the System of Placement and Protection Indonesian Migrant Workers, and BNP2TKI

61 Thomas Buergenthal \& Harold G. Maier, Public International Law in A Nutshell 115 (2006).

62 Ministry of Manpower and Transmigration, The Ministry of Manpower and Transmigration of RI to Stop TKI Placement as Domestic Workers by 2017, INDONESIA.GO.ID (2012), http://www.indonesia.go.id/kementerian/kementerian/ kementerian-tenaga-kerja-dan-transmigrasi/497-ketenagakerjaan/10279kemnakertrans-tergetkan-hetikan-penempatan-tki-domestik-worker-tahun-2017. html.

63 Buchori \& Amalia, supra note 4.

64 Due to the shortage of provisions in the law on the protection migrant workers, it is now scheduled for an amendment in Parliament. It only has seven articles out of 109 articles that are concerned with protection compared to sixty-six articles regarding placement. 
("Agency") was established by Government Regulation 81/2006. The Agency accordingly has the main responsibility "for implementing policies in the field of placement and protection of Indonesian workers in foreign countries in a coordinate and integrated manner" as stated in Article 95 of Law 39. Its purpose is to coordinate the various stakeholders involved in the migration chain process, namely, private labor Indonesian companies (PPTKIS), agencies abroad, and non-governmental organizations, Indonesian embassies abroad, as well as the host countries themselves. It is charged to cover, inter alia, recruitment, health check, training, departure, and in-country protection. It also should engage in cooperation with the Ministry of Manpower and Transmigration, ${ }^{65}$ Ministry of Internal Affairs, ${ }^{66}$ Ministry of Health, ${ }^{67}$ Directorate General of Immigration (with Ministry of Law and Human Rights), ${ }^{68}$ and Ministry of Foreign Affairs. ${ }^{69}$ Based on this coordination and cooperation, the Agency will issue a Migrant Worker Card which is given to migrant workers just before they depart for destination countries (Kartu Tenaga Kerja Luar Negeri, KTLN).

The Indonesian government tries to utilize diplomatic channels to protect migrant workers through bilateral and multilateral agreements with the destination states. Indonesia has Mandatory Consular Notification agreements with seven destination countries. The existence of this agreement assures that the destination country will notify the Indonesian Embassy promptly when Indonesian nationals are injured. ${ }^{70}$ Indonesia also has some government to government agreements. For example, the Indonesia-Japan agreement concerning the placement of nurses to Japan,

65 Ministry of Manpower and Transmigration is the leading government agency for the regulation of Indonesian migrant workers. Recruitment and placement are conducted by private agencies, which are licensed by the Ministry. The Ministry also monitors pre-departure training, a compulsory pre-departure briefing, and provide a limited number of labor attachés at Indonesian embassies abroad.

66 For issuing the ID card of candidates.

67 For medical checkup of the candidates.

68 For the issuance of the passport.

69 For the legal status of job orders, i.e., the Indonesian embassies in the destination states.

70 Lina Hastuti and Koesrianti, MCN sebagai Upaya Pemerintah Melindungi TKI di Luar Negeri (MCN as a Government Means to Protect Indonesian Migrant Workers Abroad), Research Report, unpublished, 2009 
Indonesia-Timor Leste agreement for sending caregivers and midwives, and Indonesia-South Korea agreement concerning industries, manufacturing, agriculture, fisheries, and services. ${ }^{71}$ At the regional level, Indonesia is a party to the ASEAN Declaration on Migrant Worker 2007 that expresses the commitment of ASEAN member countries, both sending and receiving states, in fulfilling their obligations to provide protection to migrant workers from ASEAN member countries. ${ }^{72}$ At the international level, Indonesia has ratified the International Convention on the Protection of Rights of All Migrant Workers and Their Families. ${ }^{73}$

There are many Indonesians who were jailed in destination countries for committing various crimes such as fraud, adultery, and sorcery. Indonesian migrant workers facing death sentences stood at 420 , in five countries, with Malaysia accounting for the highest number at 351, 45 in Saudi Arabia, 22 in China, Singapore, and the Philippines with one each. Ninety-nine have already been sentenced to death. ${ }^{74}$

In order to minimize the number of the migrant workers being sentenced to death, the government established the Task Force for Migrant Workers Facing Death Sentences, which has the responsibility to provide accurate data on problems relating to migrant workers as well as make suggestions to the governments. Based on the data collected and suggestions made, the government has arranged for high-level diplomacy under the direct command from the President and for providing legal aid for migrant workers. Between 2010 and 2012, the Saudi government pardoned more than 500 jailed Indonesian migrant workers. ${ }^{75}$ In early 2011 , follow-

71 Neneng Zubaidah, Pemerintah Buka Peluang Penempatan TKI di 6 Negara, SINDONEws.CoM, Jan. 31, 2013, http://nasional.sindonews.com/read/713068/15/ pemerintah-buka-peluang-penempatan-tki-di-6-negara-1359640258.

72 ASEAN Declaration on the Protection and Promotion of the Rights of Migrant Workers, Jan. 13, 2007, available at http://www.asean.org/communities/aseanpolitical-security-community/item/asean-declaration-on-the-protection-andpromotion-of-the-rights-of-migrant-workers-3.

73 Indonesia has ratified this Convention by Act No. 6 in 2012.

74 Faisal Maliki Baskoro, Indonesia's Migrant Workers Still Lacking Government Protection, Jakarta Globe (Dec. 19, 2012, 8:44 AM), http://www.thejakartaglobe. com/archive/indonesias-migrant-workers-still-lacking-govt-protection.

75 Edi Hardum, Saudi Arabia Pardons 141 Jailed Migrant Workers From Indonesia, JaKARTA Globe (Apr. 29, 2013, 8:30 PM), http://www.thejakartaglobe.com/news/ 
ing several reported cases of maltreatment and violent abuse and after an Indonesian worker was beheaded resulting from a conviction of murder of a Saudi employer, Indonesia stopped sending maids to Saudi Arabia. ${ }^{76}$ The Kingdom of Saudi Arabia is the Middle East's largest market for Asian domestic helpers. ${ }^{77}$ The recent data in the Ministry of Foreign Affairs indicated that in 2012 the number of Indonesian nationals who were sentenced to death stood at 121 cases, 74 were freed, and 219 were still in the process. From March 2013, there were 19 cases, 6 were freed, and 232 still in the process. ${ }^{78}$

\section{c. The Sending State Responsibility upon Return Home of Migrant Workers}

Migrant domestic workers are still facing maltreatment upon their return home. They may encounter difficulties in reintegrating into the labor market of their home country since the type of work they engage in abroad does not match with the availability of employment at home. Also, migrant workers have difficulties adapting with society due to their prolonged absence from their home country. Migrant workers also have difficulties with their pensions and social security benefits when they retire. It is important to note that the money saved and remitted by migrant workers is put to productive use, and has contributed to job creation in sending countries. While returning Filipino migrant workers have access to a number of credit loans, their Indonesian counterparts have not been offered the same.

saudi-arabia-pardons-141-jailed-migrant-workers-from-indonesia.

76 Reyna Usman, Director General of Promotion and Placement of Workers, Ministry of Manpower and Transmigration (Direktorat Jenderal Pembinaan Penempatan Tenaga Kerja Kementrian Tenaga Kerja dan Transmigrasi RI), Proyeksi Reformasi Kebijakan dan Regulasi di Bidang Penempatan dan Perlindungan Tenaga Kerja Indonesia di Luar Negeri, Rapat Koordinasi Nasional (RAKORNAS) Perlindungan WNI/BHI dengan Seluruh Perwakilan RI dan Diaspora, Jakarta, 18 Agustus 2013, Indonesian Government issued a moratorium to Saudi Arabia on 1 August 2011.

77 Directorate of Protection Indonesian Citizens and Legal Entities Ministry of Foreign Affairs of Republic Indonesia, Peran Negara dalam Melindungi WNI di Luar Negeri: Permasalahan dan Langkah Langkah Strategis, Forum Komunikasi Kelitbangan, Makasar, 6 Desember 2011, The number of Indonesian migrant worker in Saudi Arabia was 555,813, Malaysia 347,989, Taiwan 150,768, Id.

78 Tatang Budi Utama Razak, supra note 11. 
Many migrants are unable to seek remedies for violations of their rights by employers because their period of employment has been terminated and they are not entitled to stay longer. In many cases, migrant workers return to their home country with less compensation than they are due with no possibility of seeking full compensation and remedies. It is the responsibility of the government to seek a solution for returning migrant workers to sustain their financial security and benefits. Financial literacy training and soft loans can be used to overcome this problem as many migrant workers and their families are underserved by the formal financial services industry and possess limited levels of financial literacy.

\section{d. The Decent Work for Domestic Workers Convention and Recommendation as a Direct Protection of Migrant Workers}

The regulation of domestic workers will change dramatically due to the adoption of the ILO Convention on domestic workers. At the $100^{\text {th }}$ session of the ILO Conference in June 2011, the ILO adopted Convention No. 189 and accompanying Recommendation $201 .^{79}$ The adoption of the Convention represents a key milestone on the path to the realization of decent work for domestic workers. Based on ILO research there are more than 53 million domestic workers in the world ages between 15 years old and above. ${ }^{80}$

Convention No. 189, Article 21, paragraph 2 provides that the Convention shall come into force twelve months after the date on which the ratifications of two members have been registered with the Director-General. ${ }^{81}$ It received the two requisite ratifications (from Uruguay on June 4, 2012 and the Philippines on September 5, 2012) which will enable it to enter into force a year from the date that the second ratification was registered with the ILO's Director General. ${ }^{82}$ Therefore the Convention entered into force on September 5, 2013.

79 Convention No. 189, supra note 34.

80 Mark Tran, ILO urges better pay and conditions for 53 million domestic workers, THE GuARDian (Jan. 9, 2013), http://www.guardian.co.uk/global-development/2013/ jan/09/ilo-better-pay-domestic-workers.

81 Convention No. 189 , supra note 34 , art. $21, \S 2$.

82 Until June 2013, there were seven countries that have ratified the Convention, namely, Bolivia, Italy, Mauritius, Nicaragua, Paraguay, the Philippines, and Uruguay. Indonesia has not yet ratified Convention No. 189. 
Domestic work is defined broadly in Article 1 of Convention No. 189 as "work performed in or for a household or households." The scope of domestic work includes a broad range of responsibilities, functions, and tasks, often invisible and undervalued, undertaken in and for a household. ${ }^{83}$ Meanwhile, the domestic worker is defined as "any person engaged domestic work within an employment relationship." ${ }^{44}$ It clearly states that a person who performs domestic work only occasionally or sporadically and not on an occupational basis is not a domestic worker. ${ }^{85}$

The Convention establishes that the fundamental principles and rights at work in relation to domestic workers are the following:

(a) freedom of association and the effective recognition of the right to collective bargaining;

(b) the elimination of all forms of forced or compulsory labor;

(c) the effective abolition of child labor; and

(d) the elimination of discrimination in respect of employment and occupation. ${ }^{86}$

Furthermore, Convention No. 189 provides that domestic workers enjoy effective protection against all forms of abuse, harassment, and violence. ${ }^{87}$ Also, the Convention stated that domestic workers, similar to workers generally, enjoy fair terms of employment as well as decent working conditions, and if they reside in the household, decent living conditions that respects their privacy. ${ }^{88}$

The working hours of domestic work has been regulated in such way so that domestic workers have normal hours of work. They also can have overtime compensation, periods of daily and weekly rest and paid annual leave in accordance with national laws, regulations or collective agreements,

83 Adelle Blackett, The Decent Work for Domestic Workers Convention and Recommendation, 106 American Journal of International LAW 778, 779 (2011).

84 Convention No. 189, supra note 34, art. 1.b Citation.

85 Id. art. 1.c Citation.

$86 \quad I d$. art. $3, \S 2$.

$87 \quad$ Id. art. 5.

$88 \quad$ Id. art. 6. 
taking into account the special characteristic of domestic workers. ${ }^{89}$ This will change the customary expectation across jurisdictions that "servants" will constantly be available to their "masters" to perform all required duties "within the reasonable limits of their physical strength and moral welfare." ${ }^{0}$ Thus, domestic workers, just like other workers generally, will have normal hours of work, overtime compensation, right to a daily and weekly rest, and paid annual leave. This will give better protection for the rights and condition of domestic workers.

Unlike the common practice for domestic worker employment, Convention No. 189 states that the member state shall ensure that domestic workers are informed of the terms and conditions of their employment in written contracts in accordance with national laws with details of the terms. In relation to the migrant domestic worker, the Convention in Article 8 states as follows:

National laws and regulations shall require that migrant domestic workers who are recruited in one country for domestic work in another receive a written job offer, or contract of employment that is enforceable in the country in which the work is to be performed, addressing the terms and conditions of employment referred to in Article 7, prior to crossing national borders for the purpose of taking up the domestic work to which the offer or contract applies. ${ }^{91}$

Convention No. 189 further states that "Members shall take measures to cooperate with each other to ensure the effective application of the provisions of this Convention to migrant domestic workers." ${ }^{92}$ This means that the administrative work for migrant workers should be completed in the sending state prior to their departure. The provisions of the Convention, once ratified, will empower domestic workers all over the world.

89 Id. art. 10.

90 Erna Magnus, The Social, Economic, and Legal Conditions of Domestic Servants: I, 30 International LaW Review 190, 206 (1934).

91 Convention No. 189, supra note 34, art. 8.

92 Id. 


\section{CONCLUSION}

The protection of Indonesian migrant domestic workers should be handled thoroughly and involve the commitments of all stakeholders concerned with the migration administrative process. The majority of workers that the Indonesian government has sent to foreign countries are domestic migrant workers. This has become the root problem for the protection of Indonesian migrant workers. Domestic work is undervalued, isolated, and deemed unimportant such that migrant worker are at a heightened risk of certain forms of exploitation and abuse. In addition, there is the omission of express references to either domestic work or domestic workers in a broad range of national and international regulations. Yet, domestic migrant workers make substantial financial contributions to sending states as they send remittances back home. Therefore, the protection of domestic migrant workers is indispensable. In order to protect migrant domestic workers abroad, the Indonesian government has established regulations and created institutions. However, it appears that the cooperation and coordination between these institutions are not strong enough to overcome the problems. Indeed, there are overlapping jurisdictions between them creating difficulties.

Accordingly, the sending state is responsible for the entire processes of migration for domestic workers beginning with recruitment to employment to their return when they become subject to exploitation and abuse. However, the protection of migrant workers in the employment stage is the most difficult because they are beyond the jurisdiction of the sending states. In this case, theoretically, Indonesia as a sending state can intervene based on the principle of state responsibility along with diplomatic protection so that migrant workers are under the protection of international human rights. The adoption of Convention No. 189 in 2011 has changed the treatment and condition of domestic workers all over the world. Indonesia should ratify this Convention as it will support the Indonesian government's effort to give protection to domestic migrant workers. 